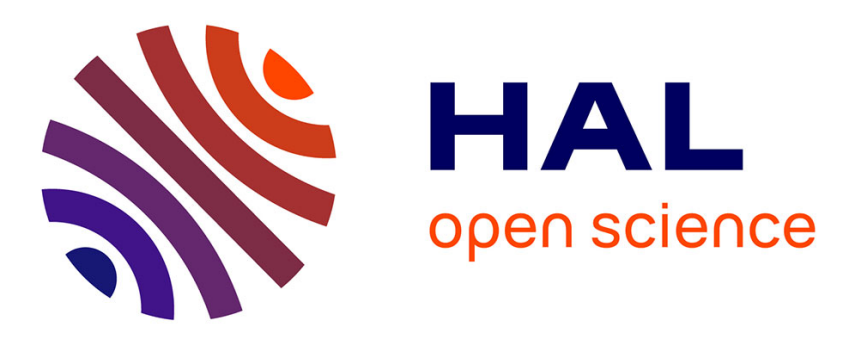

\title{
Alkali and alkaline earth metal ion binding by a foldamer capsule: selective recognition of magnesium hydrate
}

\author{
Pedro Mateus, Barbara Wicher, Yann Ferrand, Ivan Huc
}

\section{To cite this version:}

Pedro Mateus, Barbara Wicher, Yann Ferrand, Ivan Huc. Alkali and alkaline earth metal ion binding by a foldamer capsule: selective recognition of magnesium hydrate. Chemical Communications, 2017, 53 (67), pp.9300-9303. 10.1039/C7CC05422J . hal-01831995

\section{HAL Id: hal-01831995 https://hal.science/hal-01831995}

Submitted on 6 Jul 2018

HAL is a multi-disciplinary open access archive for the deposit and dissemination of scientific research documents, whether they are published or not. The documents may come from teaching and research institutions in France or abroad, or from public or private research centers.
L'archive ouverte pluridisciplinaire $\mathbf{H A L}$, est destinée au dépôt et à la diffusion de documents scientifiques de niveau recherche, publiés ou non, émanant des établissements d'enseignement et de recherche français ou étrangers, des laboratoires publics ou privés. 


\title{
Alkali and alkaline earth metal ion binding by a foldamer capsule: selective recognition of magnesium hydrate ${ }^{\dagger}$
}

\author{
Pedro Mateus, ${ }^{a}$ Barbara Wicher, ${ }^{b}$ Yann Ferrand ${ }^{\mathrm{a}}$ and Ivan Huc*a \\ a Univ. Bordeaux and CNRS, CBMN (UMR 5248), IECB, 2 rue Robert Escarpit, F-33600 Pessac, France. E-mail: i.huc@iecb.u- \\ bordeaux.fr. ${ }^{b}$ Department of Chemical Technology of Drugs, Poznan University of Medical Sciences, Grunwaldzka 6, 60-780 \\ Poznan, Poland.
}

\begin{abstract}
Alkali and alkaline earth metal ion binding by an aromatic oligoamide foldamer was shown to induce its folding into a helical capsule. CD and NMR titrations revealed tight and selective binding of $\mathrm{Mg}^{2+}$. Crystallographic studies demonstrated that, depending on the metal, binding may involve the first or second coordination spheres of the metal hydrates.
\end{abstract}

Aromatic helical foldamers and related macrocycles have emerged as versatile bioinspired containers for molecular recognition. ${ }^{1-5}$ When foldamer helices possess reduced diameters at both extremities they form capsules that sequester guest molecules and isolate them from the solvent. ${ }^{3 g-k, 5 f}$ In sequences based on aza-aromatic oligoamides, the helix inner wall is composed of numerous hydrogen bond donors and acceptors that may give rise to tight, selective, and diastereoselective binding of polyhydroxylated guests such as monosaccharides, ${ }^{3 k}$ and organic hydroxy-acids. ${ }^{3 i j}$ We have recently introduced sequence 1 (Fig. 1) whose central pyz-pyrpyz segment was shown to bind to transition metal ions $\mathrm{Cu}(\mathrm{I})$, $\mathrm{Cu}(\mathrm{II})$ and $\mathrm{Ag}(\mathrm{I})$ in such a way that the metal sits on the cavity wall and that part of its coordination sphere remains available to contribute to the recognition of an organic guest. ${ }^{6}$ Metal ion binding was also shown to drive helical folding: in the absence of metal ion, the pyz-pyr-pyz segment exists in an anti-anti conformation favoured by repulsion between endocyclic nitrogen atoms (Fig. 1c) that confers the oligomer with an extended conformation in which the two hemi-capsules are not facing each other (Fig. 1a, centre).

Here we report the binding of alkali and alkaline-earth metal ions by sequence 1 . The outer s-electron shell of these metal ions does not promote an affinity of pyridine-based ligands as large as that of transition metals. We nevertheless find that $\mathrm{Na}^{+}, \mathrm{K}^{+}, \mathrm{Mg}^{2+}, \mathrm{Ca}^{2+}$ and $\mathrm{Ba}^{2+}$ all bind to 1 and induce its folding in a helix; outstanding affinity and selectivity for $\mathrm{Mg}^{2+}$ was observed. The hydration sphere of the metals is essential to the binding process to such an extent that, in the case of $\mathrm{Mg}^{2+}, \mathrm{Ca}^{2+}$ and $\mathrm{Ba}^{2+}$ binding does not involve the pyzpyr-pyz segment as a first coordination sphere ligand. Instead, the first coordination sphere water molecules undergo second coordination sphere interactions with the capsule that are so strong that they overcome helix folding in the case of barium nona-hydrate, a guest too large to fit in the cavity.

Titrations of 1 ( $1 \mathrm{mM}$ ) with $\mathrm{Na}^{+}, \mathrm{K}^{+}, \mathrm{Mg}^{2+}, \mathrm{Ca}^{2+}$ and $\mathrm{Ba}^{2+}$ in $\mathrm{CDCl}_{3} / \mathrm{CD}_{3} \mathrm{CN}$ (6:4 vol/vol) were monitored by ${ }^{1} \mathrm{H} \mathrm{NMR}$. In each case, a new set of sharp signals emerged indicating the formation of a metal complex in slow exchange on the NMR timescale with uncomplexed 1 (Fig. 2a and Figs. S6-10 in the
ESI). Saturation was reached at 1 equiv. of metal ion, showing that binding is too strong $\left(K_{\mathrm{a}}>10^{5} \mathrm{M}^{-1}\right)$ to be accurately determined by this technique. Complexes with $\mathrm{Na}^{+}, \mathrm{K}^{+}, \mathrm{Mg}^{2+}$ and $\mathrm{Ca}^{2+}$ display six amide $\mathrm{NH}$ signals consistent with the conservation of the average $C_{2}$ symmetry of the helix. In contrast, the $\mathrm{Ba}^{2+}$ complex displays many more signals that span over a wider chemical shift range, indicating a loss of symmetry of the complex and the possible coexistence of several binding modes. Signals found at lower fields (>12 ppm) mark weaker ring current effects associated with aromatic stacking and thus a possible perturbation of the helical structure.

(a)

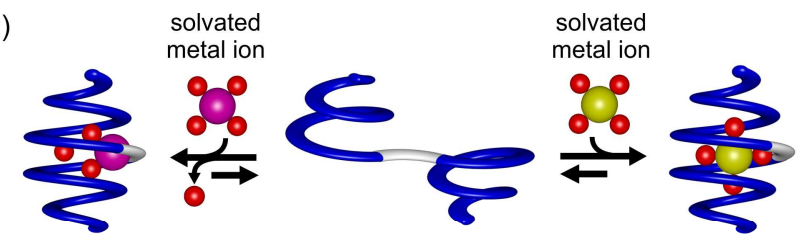

(b)

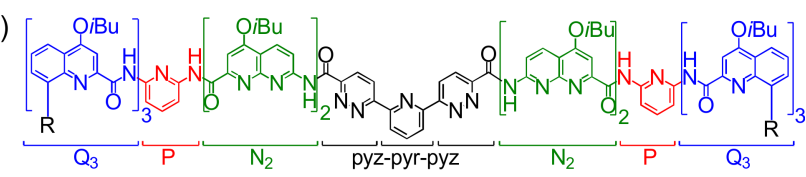

1: $\mathrm{R}=\mathrm{NO}_{2}$

2: $\mathrm{R}=\underbrace{\mathrm{O}}_{\mathrm{O}} \mathrm{C}_{(1 S)}^{\mathrm{N}}$

(c)

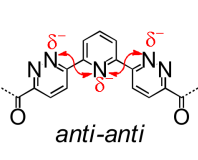

guest binding conformation

Fig. 1 (a) Schematic representation of metal-induced folding modes of a helicalcapsule: first-sphere coordination (left) and second-sphere coordination (right). (b) Formula of aromatic oligoamide sequences 1 and 2 . Q, N, P, pyz and pyr stand for 8-amino-2-quinolinecarboxylic acid, 7-amino-1,8-naphthyridine-2-carboxylic acid, 2,6-diaminopyridine, pyridazine and pyridine monomers, respectively. (c) guest.

Further titrations were monitored by $C D$ spectroscopy using 2 ( $0.03 \mathrm{mM})$ in $\mathrm{CDCl}_{3} / \mathrm{CD}_{3} \mathrm{CN}$ (6:4 vol/vol). This sequence is equipped with terminal (1S)-(-)-camphanyl groups (Fig. 1b) that quantitatively induce $P$ helicity. ${ }^{7}$ The $Q_{3} P N_{2}$ segments of 2 should thus both be $P$-helical regardless of the conformation of the central pyz-pyr-pyz and give rise to a positive CD band in the $350-400 \mathrm{~nm}$ region. ${ }^{8}$ Yet the anti-anti to syn-syn conformational change induced by the metal ion was found to be associated with a substantial increase of the molar ellipticity (Fig. 2b,c and Figs. S1-5 in the ESI) as the syn-syn 

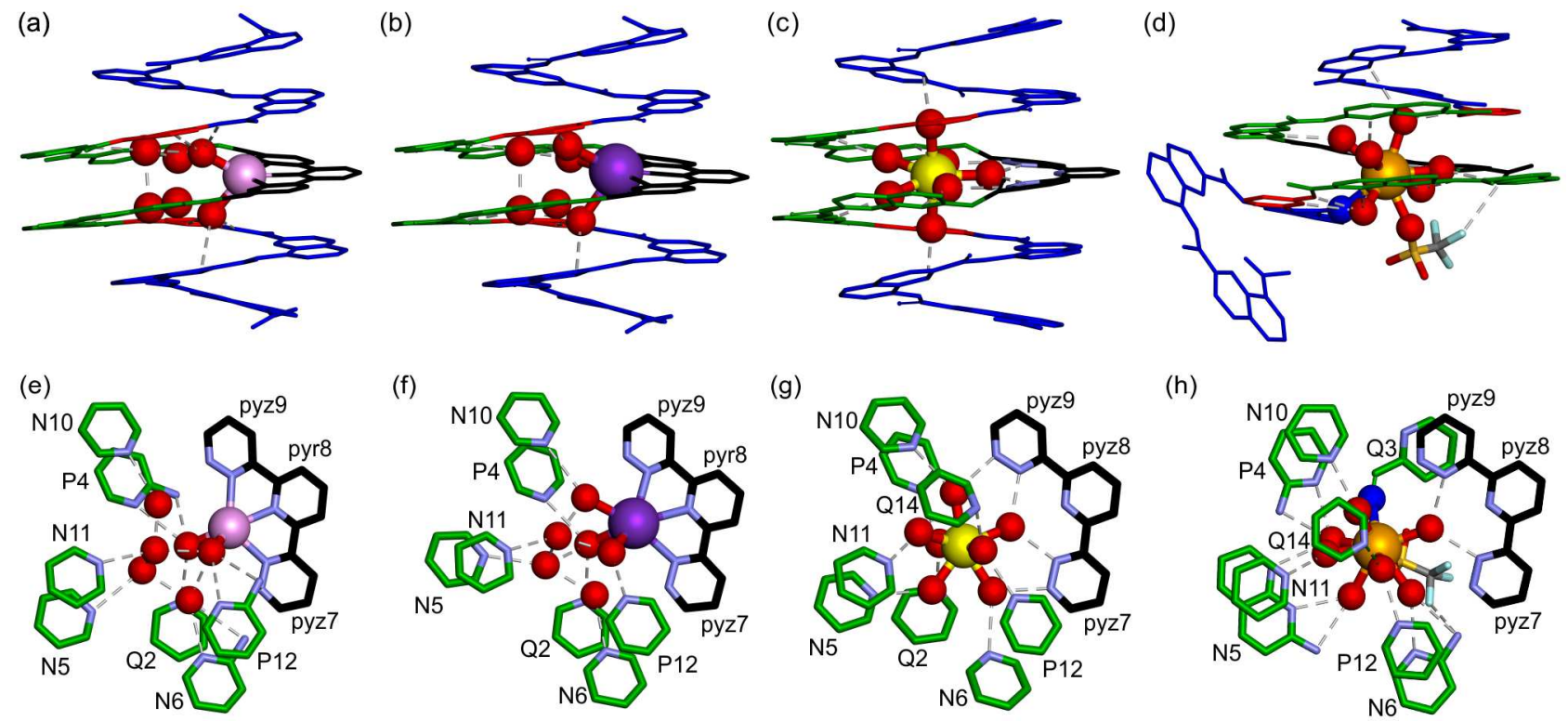

(i) Q1 Q2 Q3 $\quad$ P4 $\quad$ N5 $\quad$ N6 6 pyz7

Fig. 4 Solid-state structures of complexes formed between capsule $\boldsymbol{P - 1}$ and $(\mathrm{a})\left[\mathrm{Na}\left(\mathrm{H}_{2} \mathrm{O}\right)_{2}\right]^{+} ;(\mathrm{b})\left[\mathrm{K}\left(\mathrm{H}_{2} \mathrm{O}\right)_{3}\right]^{+} ;(\mathrm{c})\left[\mathrm{Ca}\left(\mathrm{H}_{2} \mathrm{O}\right)_{7}\right]^{2+}$ and $(\mathrm{d})\left[\mathrm{Ba}\left(\mathrm{H}_{2} \mathrm{O}\right)_{7}\right]^{2+}$. Top view of the complexes of $\boldsymbol{P}$-1 with (e) $\left[\mathrm{Na}\left(\mathrm{H}_{2} \mathrm{O}\right)_{2}\right]^{+}$; (f) $\left[\mathrm{K}\left(\mathrm{H}_{2} \mathrm{O}\right)_{3}\right]^{+} ;(\mathrm{g})\left[\mathrm{Ca}\left(\mathrm{H}_{2} \mathrm{O}\right)_{7}\right]^{2+}$ and $(\mathrm{h})\left[\mathrm{Ba}\left(\mathrm{H}_{2} \mathrm{O}\right)_{7}\right]^{2+}$, showing the heterocycles that interact with the metal ions and wate molecules. Dashed lines indicate hydrogen bonds. Hydrogen bonding distances can be found in the Supplementary Tables S3, S6, S9 and S12. (i) Numbering of the units of sequence 1 used in this figure. Isobutoxy side chains and cavity-excluded solvent molecules and counterions are omitted for clarity. The capsule backbone is represented in sticks. Sodium, potassium, calcium and barium atoms are represented in pink, purple, yellow and orange scaled balls, respectively. Oxygen atoms of water molecules are depicted as red balls. Blue ball in (d) and (h) represents a carbonyl oxygen atom.

hydrogen bonds with endocyclic nitrogen atoms of the capsule inner wall, i.e. second coordination sphere interactions, contributing to stabilize the complex and the helical structure. Additional water molecules occupy the remaining space and hydrogen bond to both the capsule and the complex. Interestingly, the number and positions of these water molecules are similar for $1 \supset \mathrm{Na}^{+}$and $\mathbf{1} \supset \mathrm{K}^{+}$.

The crystal structure of $1 \supset \mathrm{Ca}^{2+}$ (Fig. 4c) showed an encapsulated calcium ion fully surrounded by water molecules. Here the cation is bound through second-sphere coordination only, with the seven water molecules of its hydration shell establishing hydrogen bonds with the capsule. One water molecule was found to hydrogen bond to the pyz-pyr-pyz unit and to occupy the position where metal ions are found when they directly coordinate to nitrogen atoms (see Fig. S18). This water presumably stabilizes the syn-syn conformation, and contributes to helical folding. In the absence of structure, we can only speculate that $\mathrm{Mg}^{2+}$ is bound in way similar to $\mathrm{Ca}^{2+}$.

The crystal structure of the $1 \supset \mathrm{Ba}^{2+}$ complex revealed an unexpected unfolding pattern with one terminal $Q_{3}$ cap flipped away from the helix, allowing the $\mathrm{Ba}^{2+}$-triflate ion pair to protrude out of the cavity (Fig 4d). Capsule opening occurs most likely because the hydrated barium is too voluminous to fit in the closed cavity. The local disruption of the helix to accommodate $\mathrm{Ba}^{2+}$ must have a high enthalpic price and illustrates the avidity of the capsule inner wall for these metal hydrates. Nevertheless, the conformational penalty results in weaker binding for $\mathrm{Ba}^{2+}$. As for $\mathrm{Ca}^{2+}, \mathrm{Ba}^{2+}$ does not directly coordinate to the pyz-pyr-pyz unit but interacts through a water molecule (Fig. S19). Binding is thus mostly through second sphere coordination but for one carbonyl oxygen atom of a Q-P amide bond that coordinates directly to the metal. A triflate completes the first coordination sphere. It is the only anion observed coordinating the metal ion among all four structures, indicating that in most cases, negative charges are borne by water molecules.

The prime role of second-sphere coordination, i.e. hydrogen bonds, to encapsulate $\mathrm{Ca}^{2+}$ and $\mathrm{Ba}^{2+}$ called for additional experiments to tests the stability of these complexes in presence of a solvent that competes for hydrogen bonding. Adding $5 \% \mathrm{DMSO}^{-\mathrm{d}_{6}}(\mathrm{vol} / \mathrm{vol})$ to the complexes leads to release of $\mathrm{Mg}^{2+}, \mathrm{Ca}^{2+}$ and $\mathrm{Ba}^{2+}$, while $\mathrm{Na}^{+}$ and $\mathrm{K}^{+}$remain bound even in the presence of $30 \%$ DMSO- $\mathrm{d}_{6}$. This is fully consistent with the binding modes found in the crystal structures. Only when first-sphere coordination to pyzpyr-pyz is involved does the complex resist the presence of DMSO. In contrast, the binding mode of the metal hydrates of $\mathrm{Mg}^{2+}, \mathrm{Ca}^{2+}$ and $\mathrm{Ba}^{2+}$ resembles that of organic hydroxy acids and of monosaccharides. ${ }^{3 i-k}$

This investigation thus expands the scope of molecular recognition by aromatic helical foldamers, in particular with respect to metal binding via second-sphere coordination and with respect to the reported high selectivity for magnesium.

This work was supported by the European Union (H2020MSCA-IF-2015-707071 - RAMSES, postdoctoral fellowship to PM).

\section{Notes and references}

1 Reviews: (a) H. Juwarker, J.-m. Suk and K-S. Jeong, Chem. Soc. Rev., 2009, 38, 3316; (b) I. Saraogia and A. D. Hamilton, Chem. Soc. Rev., 2009, 38, 1726; (c) B.-B. Ni, Q. Yan, Y. Ma and D. Zhao, Coord. Chem. Rev., 2010, 254, 954; (d) K. Yamato, M. Kline and B. Gong, Chem. Commun., 2012, 48, 12142; (e) D.-W. Zhang, X. Zhao and Z.-T. Li, Acc. Chem. Res., 2014, 47, 1961. 
2 For recognition of rod-like guests see: (a) A. Tanatani, M. J. Mio and J. S. Moore, J. Am. Chem. Soc., 2001, 123, 1792; (b) T. Nishinaga, A. Tanatani, K. Oh and J. S. Moore, J. Am. Chem. Soc., 2002, 124, 5934; (c) A. Tanatani, T. S. Hughes and J. S. Moore, Angew. Chem., Int. Ed., 2002, 41, 325; (d) Q. Gan, Y. Ferrand, C. Bao, B.Kauffmann, A. Grelard, H. Jiang and I. Huc, Science, 2011, 331, 1172; (e) Q. Gan, Y. Ferrand, N. Chandramouli, B. Kauffmann, C. Aube, D. Dubreuil and I. Huc, J. Am. Chem. Soc., 2012, 134, 15656; (f) Q. Gan, X. Wang, B. Kauffmann, F. Rosu, Y. Ferrand and I. Huc, Nat. Nanotech., 2017, 12, 447.

3 Neutral guest recognition: (a) V. Berl, M. J. Krische, I. Huc, J.M. Lehn and M. Schmutz, Chem. - Eur. J., 2000, 6, 1938; (b) J.-L. Hou, X.-B. Shao, G.-J. Chen, Y.-X. Zhou, X.-K. Jiang and Z.T. Li, J. Am. Chem. Soc., 2004, 126, 12386; (c) M. Inouye, M. Waki and H. Abe, J. Am. Chem. Soc., 2004, 126, 2022; (d) H. Abe, H. Machiguchi, S. Matsumoto and M. Inouye, J. Org. Chem., 2008, 73, 4650; (e) C. Li, G.-T. Wang, H.-P. Yi, X.-K. Jiang, Z.-T. Li and R.-X. Wang, Org. Lett.,2007, 9, 1797; (f) M. Waki, H. Abe and M. Inouye, Angew. Chem., Int. Ed. 2007, 46, 3059; (g) C. Bao, B. Kauffmann, Q. Gan, K. Srinivas, H. Jiang and I. Huc, Angew. Chem., Int. Ed., 2008, 47, 4153; (h) J. Garric, J-M. Léger and I. Huc, Angew. Chem., Int. Ed., 2005, 44, 1954; (i) Y. Ferrand, A. M. Kendhale, B. Kauffmann, A. Grélard, C. Marie, V. Blot, M. Pipelier, D. Dubreuil and I. Huc, J. Am. Chem. Soc., 2010, 132, 7858; (j) G. Lautrette, B. Wicher, B. Kauffmann, Y. Ferrand and I. Huc, J. Am. Chem. Soc., 2016, 138, 10314; (k) N. Chandramouli, Y. Ferrand, G. Lautrette, B. Kauffmann, C. D. Mackereth, M. Laguerre, D. Dubreuil and I. Huc, Nat. Chem., 2015, 7, 334; (I) H. Q. Zhao, S. Sheng, Y. H. Hong and H. Q. Zeng, J. Am. Chem. Soc., 2014, 136, 14270; (m) H-G. Jeon, J. Y. Jung, P. Kang, M-G. Choi and K-S. Jeong, J. Am. Chem. Soc., 2016, 138, 92.

4 Cation recognition: (a) R. B. Prince, T. Okada and J. S. Moore, Angew. Chem., Int. Ed., 1999, 38, 233; (b) A. Petitjean, L. A. Cuccia, J-M. Lehn, H. Nierengarten and M. Schmutz, Angew. Chem., Int. Ed., 2002, 41, 1195; (c) Y.Zhao and Z. Zhong, J. Am. Chem. Soc., 2006, 128, 9988; (d) Z. Zhong and Y. Zhao, Org. Lett., 2007, 9, 2891; (e) K. Yamato, L. H. Yuan, W. Feng, A. J. Helsel, A. R. Sanford, J. Zhu, J. G. Deng, X. C. Zeng and B. Gong, Org. Biomol. Chem., 2009, 7, 3643; (f) J-m. Suk, V. R. Naidu, X. Liu, M. S. Lah and K-S. Jeong, J. Am. Chem. Soc. 2011, 133, 13938; (g) J. Shen, C. Ren and H. Zeng, J. Am. Chem. Soc., 2017, 139, 5387.

5 Anion recognition: (a) K.-J. Chang, B.-N. Kang, M.-H. Lee and K.-S. Jeong, J. Am. Chem. Soc., 2005, 127, 12214; (b) R. M. Meudtner and S. Hecht, Angew. Chem., Int. Ed., 2008, 47, 4926; (c) H. Juwarker, J. M. Lenhardt, D. M. Pham and S. L. Craig, Angew. Chem., Int. Ed., 2008, 47, 3740; (d) Y. Hua and A. H. Flood, J. Am. Chem. Soc., 2010, 132, 12838; (e) Y. Wang, F. Bie and H. Jiang, Org. Lett., 2010, 12, 3630; (f) Y. Hua, Y. Liu, C.-H. Chen and A. H. Flood, J. Am. Chem. Soc., 2013, 135, 14401; (g) A. L. Connor, T. Hu, C. S. F. Detchou, R. Liu, S. V. S. R. K. Pulavarti, T. Szyperski, Z. Lu and B. Gong, Chem. Commun., 2016, 52, 9905.

6 M. Horeau, G. Lautrette, B. Wicher, V. Blot, J. Lebreton, M. Pipelier, D. Dubreuil, Y. Ferrand and Ivan Huc, Angew. Chem., Int. Ed., 2017, 56, DOI: 10.1002/anie.201701693.

7 A. M. Kendhale, L. Poniman, Z. Dong, K. Laxmi-Reddy, B. Kauffmann, Y. Ferrand and I. Huc, J. Org. Chem., 2011, 76, 195.

8 Y. Ferrand, N. Chandramouli, A. M. Kendhale, C. Aube, B. Kauffmann, A. Grélard, M. Laguerre, D. Dubreuil and I. Huc, J. Am. Chem. Soc., 2012, 134, 11282.

9 (a) P. Bühlmann, E. Pretsch and E. Bakker, Chem. Rev., 1998 , 98, 1593; (b) G. R. C. Hamilton, S. K. Sahoo, S. Kamila, N. Singh, N. Kaur, B. W. Hylanda and John F. Callan, Chem. Soc. Rev., 2015, 44, 4415
10 (a) A. V. Bordunov, J. S. Bradshaw, X. X. Zhang, N. K. Dalley, X. Kou and R. M. Izatt, Inorg. Chem., 1996, 35, 7229; (b) Y. Suzuki, H. Komatsu, T. Ikeda, N. Saito, S. Araki, D. Citterio, H. Hisamoto, Y. Kitamura, | T. Kubota, J. Nakagawa, K. Oka and K. Suzuki, Anal. Chem., 2002, 74, 1423; (c) T. Shoda, K. Kikuchi, H. Kojima, Y. Urano, H. Komatsu, K. Suzuki and T. Nagano, Analyst, 2003, 128, 719; (d) Q-Z. Yang, L-Z. Wu, H. Zhang, B. Chen, Z-X. Wu, L-P. Zhang and C-H. Tung, Inorg. Chem., 2004, 43, 5195; (e) H. Komatsu, N. Iwasawa, D. Citterio, Y. Suzuki, T. Kubota, K. Tokuno, Y. Kitamura, K. Oka and K. Suzuki, J. Am. Chem. Soc., 2004, 126, 16353; (f) G. Farruggia, S. lotti, L. Prodi, M. Montalti, Ne. Zaccheroni, P. B. Savage, V. Trapani, P. Sale and F. I. Wolf, J. Am. Chem. Soc., 2006, 128, 344; (g) H. M. Kim, P. R. Yang, M. S. Seo, J.-S. Yi, J. H. Hong, S-J. Jeon, Y-G. Ko, K. J. Lee, and B. R. Cho, J. Org. Chem., 2007, 72, 2088; (h) J. Kim, T. Morozumi and H. Nakamura, Org. Lett., 2007, 9, 4419; (i) H. Hama, T. Morozumi and H. Nakamura, Tet. Letters, 2007, 48, 1859; (j) D. Ray and P. K. Bharadwaj, Inorg. Chem., 2008, 47, 2252; (k) M.Ishida, Y. Naruta and F. Tani, Angew. Chem., Int. Ed., 2010, 49, 91; (I) Y. Ma, H. Liu, S. Liua and R. Yang, Analyst, 2012, 137, 2313; (m) R. Alam, T. Mistri, A. Katarkar, K. Chaudhuri, S. K. Mandal, A. R. Khuda-Bukhsh, K. K. Dasa and M. Ali, Analyst, 2014, 139, 4022; (n) P. S. Hariharan and S. P. Anthony, RSC Adv., 2014, 4, 41565; (o) A. Pandey, A. Kumar, S. Vishwakarma, K. K. Upadhyay, RSC Adv., 2016, 6, 6724.

11 S. Watanabe, S. Ikishima, T. Matsuo and K. Yoshida, J. Am. Chem. Soc. 2001, 123, 8402

12 I. Persson, Pure Appl. Chem., 2010, 82, 1901. 